\title{
LIBERAL AND ILLIBERAL POPULISM. THE LEADERSHIP OF BERLUSCONI AND ORBÁN
}

\author{
ANDRÁS KÖRÖSÉNYII AND VERONIKA PATKÓS ${ }^{2}$
}

\begin{abstract}
The paper compares the political leadership of Silvio Berlusconi and Viktor Orbán from the beginning of their political careers to 2014, Besides giving a descriptive comparison of the Italian and Hungarian political leaders, the paper focuses on two questions: (1) the nature of their populism; (2) the quality and robustness of the changes induced by their policy. The paper concludes that both leaders introduced a new era in politics, but Orbán has been more effective in transforming policy means and priorities and also in adjusting the institutional settings (polity). Unlike Berlusconi, he has become a founder of a new regime; a democracy with authoritarian elements. Both of them are populist leaders in terms of substance, as well as process and linkage, but the ideological nature of their populism is rather different. While Berlusconi represents liberal populism, Orbán represents an illiberal one.
\end{abstract}

KEYWORDS: leadership, populism, illiberalism, Berlusconi, Orbán

Silvio Berlusconi and Viktor Orbán, the Italian and Hungarian political leaders, have often been criticized in the European press and also in the political science literature for their populist style, extravagant behavior, and even for authoritarian elements in their politics. Although the literature devotes little attention to comparing their figures, and there are few references portraying them as similar populist leaders (Conversi, 2013; Mudde, 2015; Palonen, 2009, p. 329), leading European newspapers have regularly drawn a parallel between

\footnotetext{
1 Hungarian Academy of Sciences, Centre for Social Sciences; Corvinus University of Budapest. E-mail: korosenyi.andras@tk.mta.hu

2 Hungarian Academy of Sciences, Centre for Social Sciences; Corvinus University of Budapest. E-mail: patkos.veronika@tk.mta.hu
} 
them. For example, The Economist warned EU politicians that they should not repeat the 'Berlusconi mistake' in the case of Orbán, thus they should 'condemn Mr. Orbán's anti-democratic behavior loudly and clearly' (The Economist, 2012). Others have noted that Orbán is a 'populist who learns fast' and 'wants to become another Silvio Berlusconi' (Spiegel Online, 2010). Similarly, European politicians like Sigmar Gabriel and Gianni Pittella have drawn attention to their comparable practices. Pittella remarks, 'We all remember Berlusconi's years. (...) Hungary is a great country and deserves better than this' (Socialists \& Democrats, 2015), while Gabriel suggests that the European People's Party should stop its cooperation with the parties of Berlusconi and Orbán, pointing out that 'it is wrong to make the fate of the European Union dependent on these two parties' (Reuters, 2014).

Although they may seem to be the straw men in the European political discourse, they are heavyweights in Italian and Hungarian politics. As well as with some of the superficial references in their political discourse, there are several striking similarities between these two political leaders. Both Berlusconi and Orbán have served as prime minister for long periods, carried out major institutional reforms, applied innovative campaign techniques, and presented charismatic profiles as the leaders of not only their own parties, but practically of the whole right side of the political spectrum.

Following an ancient strategy described in Plutarch's Parallel Lives, our aim is to compare the achievement of these political leaders. Plutarch compared biographies of famous men, arranging them in tandem. He tried to illuminate the impact that their moral virtues or failings had on their records as a great men or as statesmen. Our goal is slightly different and more modest: it is to focus on the achievements of Berlusconi and Orbán as individual political leaders. Political leadership might be defined as an unmistakable personal impact on politics and policies. In the words of an Austrian political scientist, Anton Pelinka (1995, 2), 'Leadership exists if politics and policies without a certain person's participation would be decidedly different'. We assume that Berlusconi and Orbán have been not just incumbents, but real political leaders in this sense. In fact, they have changed the nature of democratic politics in their own countries, even if the direction and quality of these changes are controversial and highly debated.

Thus, the aim of our paper is primarily to compare and describe their leadership achievements. We would like to highlight the similarities and differences between Berlusconi and Orbán by exploring the nature and scope of the political changes inspired and carried out by these political leaders in each country. We concentrate on the direction and the robustness of the changes they have carried out. Our aim is to say whether their politics have brought similarly deep changes in the fields of policy, ideology and institutions, beyond the superficial similarity of their extravagant, populist leadership style and rhetoric. 
We answer this question through investigating two analytical areas using a descriptive comparison. First, in what sense and to what extent can Berlusconi and Orbán be characterized as populist leaders? The application of the concept of populism in a nuanced manner will help to refine the assumptions of the existing literature. The second question is concerned with the scope and the direction of the changes. In order to map them, we use the concepts of presidentialization (Poguntke-Webb 2005) and anti-liberalism/illiberalism (Zakaria 1997). We assume that these concepts are adequate means for grasping important aspects of the changes which have occurred.

The article is organized as follows: First, we introduce the conceptual framework that supports two analytical questions regarding populism and the scope and direction of changes. The second part is devoted to a descriptive comparison of the political activity of Berlusconi and Orbán. In this section we analyze four areas, which cover the three classical dimensions of polity, politics and policy: first, their effect on the party system and on the political spectrum (politics); second, the applied political means (politics); third, the transformation of the governmental structure (polity); and fourth, governmental goals and policy. Finally, we return to the analytical questions and summarize the conclusions of the comparison. Our main finding is that both leaders have opened a new era in Italian and Hungarian politics, but based on the scope and depth of the changes, Orbán is also a founder of a new political regime.

\section{THE CONCEPTUAL FRAMEWORK OF THE ANALYSIS}

In the following section we expound on the conceptual framework of the major questions of this essay.

\section{Populism}

Our first question refers to the general assumption in the literature regarding the populist nature of the leaderships of Berlusconi and Orbán. We would like to further clarify the following question: in what sense and to what extent can Berlusconi and Orbán be characterized as populist leaders (Bozóki 2008; Pappas 2014; Pasquino 2005)? To answer the question, we use the concept of populism in three different senses: (1) as an ideology (substance); (2) as process and linkage; and (3) as constitutional politics. 
Firstly, there is wide consensus in the literature that populism as an ideology includes the following elements: (1) an assumption of a central antagonistic relationship between 'the people' and 'the elite'; (2) an attempt to give power back to the people and restore popular sovereignty; and (3) a perception of the people as a homogeneous unity (Canovan 1999; Mudde 2004; Mény and Surel 2002). In addition, populism often involves announcing a serious crisis, claiming a central position for the leader who embodies the will of the people, and conducting adversarial politics; i.e., a strategy of polarization. Besides this, however, populism is 'empty' as a substance. It is, using the concept developed by Michael Freeden, a 'thin-centred' ideology, which can be attached willynilly to any left- or right-wing political ideas (Mudde and Kaltwasser 2014).

Secondly, regarding the concept of populism as process and linkage we rely on the work of Peter Mair. Populism in this sense is a form of democratic governance that operates without an emphasis on party, where the relationship between voters and government is unmediated (Mair 2002: 88-89). There is an increased reliance on plebiscitarian techniques of winning support.

Thirdly, we introduce a constitutional-institutional dimension of populism. While Mair focused on the linkage and mediation between party leaders and followers, particularly in the process of mobilization and political will-formation, we also reflect on the mode of linkage at the constitutional and governmental level. Populist democracy as a constitutional system includes means like recall, public initiative, referendum and/or direct elections of public office-holders. We are interested in gauging the extent to which Berlusconi and Orbán used already existing means of direct democracy in their political practice, and also the extent to which they introduced or tried to introduce additional direct democratic institutions at the constitutional level.

\section{The scope and direction of changes}

The second question addressed in this essay focuses on the direction of changes that have taken place in the Berlusconi and Orbán era. The concepts of personalization, presidentialization and liberalism/illiberalism will be used to understand the direction of changes. First, personalization refers to the increasing role of political leaders vis-à-vis traditional party structures and in electoral competition (Blondel et al. 2010; Karvonen 2010). Second, we understand the de facto presidentialization of politics to be the strengthening of power resources and political autonomy of incumbent leaders in three central arenas of democratic politics and government: within the executive 
(executive face), the political party (party face), and when personalization increases in electoral politics at the same time (electoral face). The process of presidentialization is strengthened by factors other than those deriving from the formal constitutional structure (Poguntke and Webb 2005, 5). Third, the concepts of liberalism and illiberalism are used in a conventional sense within the context of liberal democracies. By liberalism here, we mean the rule of law and the constitutional limits set up for taming political power. Anti-liberalism or illiberalism, therefore, refers to endeavors to 'shirk' these constraints, often justified by democratic empowerment (Zakaria 1997).

\section{THE COMPARISON}

\section{The reshaping of the political spectrum}

Berlusconi and Orbán have carried out important modifications of the political scene and reshaped the party system with long-lasting effect. Both of them emerged from a political vacuum, both reorganized the political right in their country, and both gave a determinant direction to the changes in the party system over a long period.

Berlusconi entered Italian politics when it was undergoing a radical transformation due to both internal and international factors. After the collapse of the major parties, Berlusconi offered a center-right, liberal alternative using a new, fresh, and easily understandable tone. He reached a coalition agreement separately with two parties (the Northern League and the National Alliance) that would have never formed a coalition with each other. With the help of this strategy he won the election, becoming prime minister of a coalition cabinet composed of Forza Italia and the two allies. However, his innovation's strength was also its weakness. As Raniolo (2013: 106) says 'the first Berlusconi cabinet confirmed that electioneering was one matter and that governing was another and very different one'. Internal tensions between coalition members appeared from the beginning, and being a newcomer in politics (which was rhetorically advantageous for Berlusconi during the campaign) also meant having no experience in handling political controversies. The government took office on 10 May 1994, and was obliged to resign before the end of the same year. In spite of the failure of the first Berlusconi cabinet, his effect on political competition and on the party system has been lasting. 
One popular narrative of the establishment of Italian bipolarism is that 'bipolarism and alternation of government are fruits of the political action of Silvio Berlusconi' (Forza Italia 2013b). This implicitly means that after a long period without alternation, Italy finally became a modern European democracy. But before seeing Berlusconi as a proactive protagonist of this process, it is important to note the role of the new, semi-majoritarian electoral system that also favored the emergence of two main political blocks at the center. As Pasquino notes 'it would be more appropriate to say that Berlusconi became bipolar by default, that is, because he was obliged by the political circumstances and events to shape his own 'pole' and to structure the electoral and political competition around 'us' versus 'them" (Pasquino 2007a: 45).

In addition to the role of the new electoral system and other political circumstances, the fact remains that a few months were enough for Berlusconi to remold the dynamics of political competition and to consolidate FI's position on the center-right side of Italian political spectrum. The bipolar era lasted until the elections of 2013, when a viable movement emerged on the scene. The Movimento 5 Stelle (M5S, 5 Stars Movement) has been able to create a firm third pole more successfully than any other party or coalition during the last two decades.

The rise of Viktor Orbán as a political leader and prime minister in Hungary is closely connected to his achievement of re-shaping his own party as well as the whole political spectrum. After 1994 he entered the political vacuum left by the collapse of the center-right MDF through a masterful re-positioning of Fidesz from a left-liberal radical youth movement to a national-liberal, moderate right-wing party. By the time of the 1998 elections Orbán had become the leader of the political right. Having won the election he was able to form his first cabinet with his coalition partners from the right of the center. Since the SZDSZ, the larger liberal party, joined the Horn government and entered an enduring political alliance with the Socialist Party, the left/right conflict became a persistent divisive dimension. Hence the liberal center disappeared from Hungarian politics.

Orbán, even more successfully than Berlusconi, was able to unify the whole political right in Hungary. He successfully used his premiership between 1998 and 2002 to strengthen his position as a leader of the right. He gradually weakened his coalition partners, won their constituencies (Enyedi 2005) and either integrated them into Fidesz, or pushed them to the sidelines of politics. By the first decade of the twenty-first century, Fidesz had become a highly centralized and politically rather homogeneous 'catch-all' party. The 'one flag, one camp' strategy of Orbán contributed to the strong bipolarization of the political spectrum (Körösényi 2013) which lasted until 2010. Like Berlusconi, 
Orbán was successful in preserving his leading role on the right in spite of his electoral defeats in 2002 and 2006.

At the 2010 elections, however, Fidesz achieved a landslide victory and gained a two-thirds majority in parliament. This critical election (Enyedi and Casal Bertoa 2011) abolished the bipolar party system of the previous decade: not only did it weaken the socialists and ruin the liberals (who had formed a coalition government three times together since 1990), but it produced strong radical right (Jobbik) representation in the parliament. This way Fidesz was able to present itself as the party of the political center - the 'central field of force', as Orbán called it. The 2014 elections produced a party system in which the dominant party (Fidesz) faces a bipolar opposition: the Socialist party and other left or left liberal splinter groups from the left, and the Jobbik from the far right. Thus from 2010 onwards, Orbán's Fidesz occupied the center as a dominant party — one might even speculate about the emergence of a predominant party system in the sense Sartori (1976: 192-201) used the term (Körösényi and Patkós 2017).

To sum up: Berlusconi and Orbán have been the single and unchallenged leaders of the center-right coalitions of Italy and Hungary for the last two decades. Both entered politics in the same period and achieved political success by breaking into the political vacuum left by the collapse of established parties on the right. Both of them established a new political party, or movement. Berlusconi entered politics as a newcomer when the Italian political system was undergoing deep transformation, established the leading party of the political right, and won the elections two months after he came on the scene. Orbán, the leader of Fidesz, emerged from the radical-alternative, left-liberal field of the political spectrum, but moved to the right after the 1994 electoral collapse of the moderate-right coalition government. He repositioned his own party in a surprisingly short period and reorganized the political right. Both transformed the party systems of their countries and contributed to strong ideological bipolarization and the creation of a two-block system which lasted for a long period. In turn, from 2010 onwards we have witnessed diverging tendencies in these established two-block systems: in Italy there emerged a new movement as a third pole, M5S, while in Hungary, after the 'earthquake elections' of 2010, Fidesz held onto its dominant position at the following elections in 2014.

\section{Political means: populism and centralization}

Besides his populist rhetoric and style, a striking phenomenon was the new techniques of party-building and political mobilization Berlusconi used when he 
entered politics. His party was organized from above, using techniques of market research and involving top managers of Berlusconi's holdings. Publitalia did the lion's share of the work in the field of political marketing and campaigning, as well as in candidate selection (Stille 2012). Beyond that, we find interesting another political innovation: the use of pseudo-civic associations designed to gain public attention and political capital.

Berlusconi started the movement of Forza Italia! clubs, inaugurating the first one in December, 1993, then announced his entrance into politics. The clubs were described as autonomous associations with a strong liberal-democratic perspective that undertook cultural, social, and in a non-party political sense, political activities. The dissemination of Forza Italia! clubs was promoted by Berlusconi's TV channels, which called on every interested citizen to found a local club and to be its president. Presumably due to the seemingly non-partisan and bottom-up nature of the initiative, it was very successful. Before the 1994 national elections, the estimated number of members was around one million (Poli 2001: 46 - 47). The clubs played an important role in enhancing the visibility, reputation and credibility of Forza Italia, even though they were never integrated into the party.

In the first years, due to its top-down foundation, FI's party organization was weak. During the years in opposition the party managed to reinforce it, but the strong and direct relationship between leader and supporters has remained a dominant feature of Berlusconi's party.

During the 1990s in Hungary, Orbán re-organized Fidesz from a rather anarchic, horizontally organized youth organization into a highly centralized party controlled from the top. Besides some novelties used in the 1998 campaign, Orbán began to apply new, populist mobilization techniques after the 2002 electoral defeat. He launched the Movements of Civic Circles (Polgári Körök Mozgalma) in May 2002, which recruited more than two hundred thousand members within one year (Magyar Narancs 2003). Orbán emphasized the national, non-party character of his new movement which helped him to widen the network of political activists around Fidesz in a country where formal party membership had been discredited by the communist regime. This movement also helped to keep the morale of Fidesz supporters high during the years in opposition. ${ }^{3}$

In the autumn of 2006 unprecedentedly large demonstrations were held, and violent and prolonged riots broke out against the re-elected Gyurcsány cabinet in Budapest due to the leaked 'lying speech' of the Socialist prime minister. Although Gyurcsány survived a vote of confidence in parliament, Orbán was

3 Civic Circles were established as a variant of Berlusconi’s Forza Italia clubs.

CORVINUS JOURNAL OF SOCIOLOGY AND SOCIAL POLICY VOL. 8 (2017)3S 
able to direct the dissatisfaction of the people into constitutional channels. He mobilized them against the public policy reforms of the government via the means of direct democracy. Fidesz organized a petition for a referendum (held in 2008) against three policy initiatives of the Socialist-liberal government and won each of them. From 2009 onwards the Forum of Civic-Cooperation (Civil Összefogás Fórum), another pseudo-civic satellite organization of Fidesz, regularly organized large political rallies to protest left-liberal politics and to support Fidesz. In addition to this, several National Consultations (Nemzeti Konzultáció) were held when Fidesz was both in government and in opposition, in which each citizen received a questionnaire concerning a scheduled government public policy initiative or institutional reform plan and could express her/his views about it.

To sum up: in both the Italian and Hungarian cases we have witnessed an emergence of populist democracy in the sense of process and linkage. Populism in this sense is a form of democratic governance that operates without an emphasis on party, where the relationship between voters and government is unmediated (Mair 2002: 88 - 89). There is an increased reliance on plebiscitarian techniques of winning support.

It should be emphasized, however, that populist democracy in Italy and Hungary did not replace, but supplemented representative or party democracy. There has been no shift towards populist democracy in the constitution or in government. Institutional means of direct democracy such as recall, referendum, bounded mandate, etc. have not been established or strengthened, in spite of the fact that Italy witnessed moderate institutional reforms in the Berlusconi era, and Hungary radical constitutional engineering in the Orbán era. Although populist means were applied in mobilization and in rhetoric, and both Berlusconi and Orbán appealed directly to citizens for public approval of specific policy measures, no populist means has been applied and introduced in government or in the constitution. ${ }^{4}$ Populism, as process and linkage between leaders and citizens, proved to be an instrument of top-down political leadership, rather than a means of public deliberation or authoritative decision-making from below.

4 The only exception might be the direct election of the PM in Italy, which was introduced with the electoral reform of 2005 . 


\section{Rebuilding the political system ${ }^{5}$}

Two major institutional changes were scheduled by the second cabinet (composed of Forza Italia and three smaller parties) during the Berlusconi era: the electoral law was successfully changed in 2005 , but constitutional reforms failed. The main constitutional changes would have involved the marked strengthening of the powers of the prime minister at the expense of the president of the republic and the parliament, and the devolution of the state and a national interest veto on regional acts, but the reform was rejected by the political left and also by the vast majority of Italian scholars of constitutional law and political science. Finally, it was rejected in a referendum in 2006. Characteristically, the planned constitutional reforms, as well as the electoral reform, were strongly motivated by partisan interests. Each party leader in Berlusconi's coalition would have gained political advantages. During the process the parties of the coalition had to accept certain measures in order to obtain something important to them (Bull and Newell 2009: 54, Pasquino 2007a, 2007b).

The predominantly majoritarian old electoral law was replaced by a 'bonusadjusted proportional' system, without primaries (Renwick et al. 2009). Although in the old system 75 per cent of seats were filled in single-member districts and the new system was mostly proportional, the electoral reform cannot be interpreted as a clear move towards proportionality. The underlying logic of the new system still favored bipolar competition. Two key points that, in spite of proportional seat allocation, favored the survival of the two blocks were the necessity of forming pre-electoral coalitions with an indication there would be a coalition leader (which meant the de facto direct election of the chief executive), and a bonus for the winning coalition.

Compared to the institutional reforms characterizing Berlusconi's policy, Orbán carried out more ambitious and robust institutional engineering from the incumbent position, especially in his second premiership. The two-thirds parliamentary majority achieved at the 2010 elections opened the door for Orbán to re-build the whole institutional system of Hungarian politics and achieve a 'second revolution', ${ }^{6}$ neglecting the noisy protestations of the diminished parliamentary opposition. The new constitution and the several constitutional

5 In this section we rely on Körösényi and Patkós (2017).

6 Orbán regarded the 1990 democratic transition and the regime it established as a political failure, an unfinished and mismanaged project, and tried to differentiate himself and his party from this period using various positive and symbolic means. These means have included the introduction of a new Fundamental Law to replace the constitution, the renaming of the country from Hungarian Republic to Hungary, and a declaration of the new regime as the 'System of National Cooperation' (Nemzeti Együttmúködés Rendszere). 
amendments passed between 2010 and 2013 re-structured the whole institutional fabric of the political system and the state. The prime minister's power in government has been strengthened by various means to an unprecedented level. The power of the constitutional court vis-à-vis the government majority was constrained and the whole constitutional system of checks and balances was re-shaped. Changes have included the centralization of public administration, public health care and education, and an increase of government control in other areas. The electoral reform of 2012 not only strengthened the majoritarian elements in the mixed electoral system but helped Orbán to preserve his twothirds parliamentary majority at the 2014 general elections, in spite of having lost one-fifth of all votes as compared to 2010. In addition to the institutional changes, the Orbán era established a new practice in terms of power-wielding: a few consensual elements in parliamentary decision-making were suspended (for example, the appointments of members of the constitutional court) or bypassed (like the compulsory reconciliation process with major stakeholders by introducing the government's initiatives as bills of individual legislators) and the brute force of the supermajority has prevailed. In contrast to the case of Berlusconi, Orbán's institutional reforms mean more than a turn away from legal constitutionalism towards political constitutionalism (Bellamy 2007). By the extension of Cardinal Acts ${ }^{7}$ to more than 40 legislative areas, including public policy areas like taxation, pension and the social security system, and the appointments of Fidesz loyalists to public offices for 6,9 or 12 years, Orbán has restricted any future governments' ability to act according to their own public policy goals.

To sum up: according to political scientists, the presidentialization of the executive has taken place in Italy over the last 25 years. Berlusconi did not have a distinguished role in this process, and each government contributed to it to some extent (Calise 2005: 91-96). In contrast, the first two cabinets led by Orbán played a prominent role in the process of the robust presidentialization of the executive that has taken place in Hungary since the democratic transition in 1989-1990. These changes are characterized by the centralization of public administration and the state, politicization through political patronage, and the greater dominance of the prime minister within the government. Both Berlusconi and Orbán have established a new era in Italian and Hungarian politics, respectively. But due to the constitution-making, the centralization of the government and the rebuilding of the state, it is no overstatement to characterize Orbán as a founder of a new regime in Hungary. This is a less liberal version of democracy with more authoritarian elements.

7 Cardinal Acts can be passed or amended only by a two-thirds supermajority of parliamentarians. 


\section{Political ideology, public policy and government record}

Comparison of the political ideology, public policy and government record of the two political leaders is no easy exercise. Both have operated over a long period, and Berlusconi and Orbán became prime minister three times over a relatively long time-span, so it is not easy to make an overall assessment of either of them, nor to compare their policies. In addition, the ideological saliency / pragmatism of their policies seems to be paradoxical. To make this point clear, we rely on Vivian Schmidt's differentiation between three levels of generality of ideas; namely, philosophical, programmatic, and policy ideas (Schmidt 2014: 194-198). While Orbán has evinced a more characteristic general public philosophy, ideology or world view ${ }^{8}$ than Berlusconi, it is not accompanied by strong programmatic ideas or policy paradigms such as neo-Keynesianism or neoliberalism. Therefore, his actual public policy has usually become more flexible and rather instrumental; it is not defined by any public policy paradigm, but developed through process of bricolage, to use Martin Carstensen's concept. ${ }^{9}$ In contrast, 'Berlusconi has never articulated the principles inspiring his political action in government with reference to a precise political vision. To paraphrase de Gaulle, Berlusconi has never attempted to articulate 'a certain idea of Italy' (Pasquino 2007a: 51). Berlusconi, however, proved to be more coherent at the level of programmatic ideas: he remained an adherent of the neoliberal paradigm. Therefore his policy ideas remained less 'elastic' than those of Orbán. Keeping in mind these difficulties, and at the risk of some simplification, we now give a brief overview of the governmental philosophy, political ideas, public policy attitude, and style of the two political leaders.

Governmental philosophy. The approach of Berlusconi and Orbán to politics and governance also has a few similarities. First, both of them give priority to efficient government over representation and they regard parliament as an instrument of government rather than as an institution of fair representation. Second, they prefer quick decisions rather than lengthy consultation with stakeholders. Third, they reject liberal constitutionalism in which the 'rule

8 Orbán appeared in politics as a young radical anti-communist politician at the end of the $1980 \mathrm{~s}$. But he had turned away from these radical, anti-clerical and liberal principles towards conservative, nationalist, Christian and authoritarian values and principles by the late 1990s. Orbán has always tried to articulate principles that legitimize his policy. His concept of illiberal democracy might be connected to his general critique of Western civilization.

9 Bricolage 'entails the rearrangement of elements that are already at hand, but it may also entail the blending in of new elements that have diffused from elsewhere' (Carstensen 2011, 154). Bricolage means weaving together ideational elements from different paradigms and logics, to effect heterogeneous sets of policy ideas (Carstensen 2011, 157). 
of law' prevails over the 'rule of men'. Instead, they emphasize the role of individual leaders in politics and the individual responsibility of incumbents and decision-makers. 'Who governs': that is what matters, rather than precise legal norms and institutions. Finally, they also share a procedural approach to law and regard it purely as an instrument of politics. As we saw during the second Orbán cabinet (2010 — 2014), the constitution and the newly introduced Fundamental Law were amended a total of 18 times, while in the case of Italy, Berlusconi's ad personam laws are also famous examples of this practice..$^{10}$ But there are obvious differences as well. While the self-made millionaire Berlusconi is an individualist and a market liberal who believes in entrepreneurship and has popularized a society in which everybody is responsible for their own fate (i.e. places emphasis on individual achievement), Orbán believes in active state intervention.

Ideology, values and culture. A striking similarity between Berlusconi and Orbán is their strong anti-communism, which has characterized their political thinking throughout their careers. This rigorous anti-communist stance gradually grew into an offensive and combatant policy vis-à-vis the left and leftliberals in general. In contrast to Berlusconi's liberal perceptions, the state is not neutral for Orbán, but strongly value-laden. Although both Berlusconi and Orbán are conservative-value politicians who place emphasis on Christian and family values, there are striking differences between them. Unlike Berlusconi, Orbán has been committed to implementing Christian and conservative values in public policy and even into the Fundamental Law as well (e.g. same-sex marriage is prohibited, a church law, media law, and family support schemes have been introduced). While Orbán praises positive energy rooted in collective endeavor, and his national conservative, historicizing attitude has a strong influence on the field of cultural policy, Berlusconi, as a media tycoon and owner of commercial television channels, emphasizes individual endeavor and is a champion of infotainment culture, individualism and consumerism. The scandals concerning his private life and his personal style have also contributed to the radical transformation of popular culture and public discourse after a long period of the strict, anti-consumerist and prudish cultural policy of the First Republic (Stille 2012).

Populism, anti-elitism and rhetoric. Both Berlusconi and Orbán renewed the political language of public discourse in their own countries and started to use an optimistic and self-aware tone. Berlusconi broke with the sophisticated political language used by the political class of the First Republic and began 
to use simple language, the language of ordinary people. For the first time in post-Second World War Italian politics he emphasized that 'Italians are good just as they are', and he stated that if there were problems in society, it was the fault of institutions and politicians (Orsina 2013: 97-105). In his speeches he has frequently used positive words (such as miracle, trust, dream, love and happiness) and statements like 'Forza Italia is the victory of love over hate and envy' or that his party is the 'party of love' (Forza Italia 2013a).

The linguistic shift in Hungary was also significant, but different. Orbán broke with the modernist, technocratic and 'sociological' language which had dominated Hungarian political discourse since the late-communist period ${ }^{11}$ (Szücs 2012) and, like Berlusconi, used a vocabulary closer to the language of the ordinary people. Orbán represents a self-aware, voluntarist and optimist attitude. He rejects the defeatist attitude of Hungarian left-liberal politicians who have fostered a complex of inferiority with regard to the West regarding 'underdeveloped' Hungarian political culture.

The emotional tone, and the usage of a new, simple language, easily intelligible to ordinary people, are important novelties of both politicians' political styles and appearances. These features are usually accompanied by populist rhetoric, and also accompanied by populism in a substantive sense as well. Their rhetoric has had strong anti-establishment elements and both actors have often justified their policy by referring to the will of the people vis-à-vis corrupt political elites. Berlusconi signed a contract with the Italians during the campaigns of 2001 and 2008, and Orbán also often referred to the 2010 elections as the birth of a new social contract, which was later declared by the newly elected Hungarian parliament as well. ${ }^{12}$ Their political messages have had an anti-political tone (Pasquino 2007a; Campus 2006). Appeals against existing parties, institutions and the political class, and disdain for rules and procedures are both in line with the political mentalities of the Italian and Hungarian populations.

National identity and foreign policy. Due to traditionally strong local and regional identities and deep cultural and economic differences, Italian national identity has been fairly weak since the unification of the country. With the foundation of Forza Italia, Berlusconi identified one of the very few consensually positive constituents of national pride, the Italian national football team, which inspired his party's name and symbols. During his twenty-year presence in politics, Berlusconi contributed to the strengthening of national identity, but his nationalism is a sort of 'discreet nationalism'.

11 This language, used by the post-communist (socialist) and liberal elite, dominated political discourse until the end of the 1990s.

12 www.kormany.hu/download/d/56/00000/politikai_nyilatkozat.pdf 
In contrast, Orbán's political credo includes a strong national identity and also concern for Hungarian minorities in neighboring countries. From 2010 onwards the Orbán cabinet has been engaged in a continuous 'freedom fight' against Brussels. Orbán has successfully redirected traditional Hungarian ressentiment towards the great powers and the West against the European Union. Orbán, who was the first to demand in Hungary in 1989 that the occupying Russian troops should leave the country, has followed a pro-Russian policy within the EU since 2010. Both politicians are Euroskeptics, but Orbán is so to a much greater extent. While Berlusconi is strongly committed to Euroatlantic cooperation, Orbán emphasizes national sovereignty in policy-making within the European Union, but his Euroscepticism is also supplemented with elements of anti-globalism and with less enthusiastic support for Atlantic relations.

Economic policy. Both leaders reject egalitarianism and the social welfare policies of the left, and their governments have contributed to some extent to reducing the welfare state. The middle class and the upper-middle class are the beneficiaries of their economic and social policies. Tax cuts, fighting unemployment and creating new jobs are among the top priorities of both leaders' electoral programs.

While Berlusconi can be characterized by his liberal economic policy attitude and pro-consumerism, Orbán condemns free market liberalism, globalized capitalism and multinational financial institutions. From 2010 onwards he promoted policy which gives a strong role to the state in the economy, including massive state ownership in sectors like energy, telecommunication and public utilities. In Orbán's view, both individuals and the state are responsible for individual well-being. For instance, in employment policy he prefers community service to aid for the unemployed, but claims that it is the responsibility of the state to provide work for everybody (after 2010 the Orbán cabinet introduced a massive community service program).

From 2010 onwards Orbán became a champion of a 'workfare state' and full employment instead of a welfare state, and he favors marked state intervention in the economy. He has introduced extraordinary measures, but made them permanent as part of a larger goal to restructure social-economic redistribution in Hungary. For example, the controversial crisis tax on banking was designed not only to balance the budget, but to decrease foreign ownership in the banking sector to below 50 per cent.

Berlusconi firmly believes in entrepreneurship and in the free market. Job creation has also appeared in his famous contracts with the Italians. Otherwise, the Berlusconi cabinets have made little effort either to reduce the budget deficit and Italy's enormous public debt or to combat tax evasion (Di Quirico 2010). Compared to Berlusconi’s 'easy-going' attitude, however, Orbán’s fiscal policy 
is more conservative: as PM he followed a policy of balancing the budget and fought to reduce the foreign indebtedness of the country.

The global financial crisis has had a serious and lasting effect on both countries, but the two leaders' narratives on this topic have been completely different. Berlusconi, having been in office, tried to deny the existence of the crisis $^{13}$ - or at least, to downplay the importance of it. In contrast, Orbán dramatized the political situation. He used a vehement crisis narrative to justify extraordinary political measures and interpreted the crisis as not exclusively economic in nature, representing it as evidence of the deep political and moral crisis of Western civilization.

Both Italy and Hungary can be characterized by a strong fusion of politics and business. Berlusconi was often criticized for his conflict of interests - namely, for subordinating public interest to his personal business and political interests. Having an oligarch as prime minister weakens public morale and democracy. In Hungary, the fusion of politics and business is fostered from the opposite side. Unlike in Italy when the oligarch Berlusconi struggled for political power to secure his business and personal positions, in Hungary Orbán used political means to build up a capitalist class linked closely to party politics and to the state. Orbán's policy of strong state intervention in the economy aims at, among other things, replacing the post-communist elite and reinforcing the new counter-elite. This policy, however, has strengthened oligarchic tendencies such as giving state contracts to loyal businessmen and changing rules in an ad hoc way to put 'friendly' firms and capitalists in an advantageous position.

\section{ANALYSIS}

In the final part of this article we review the results of the comparison, then we respond to the two analytical questions of the paper. Finally, we draw some conclusions.

The comparison. We draw a distinction between the three political dimensions: polity, politics, and policy. On basis of the results of the comparison above, we assert that the leadership activity and achievement of Berlusconi and Orbán is rather similar in the dimension of politics, but in the dimensions of polity and policy we find more differences than similarities. Berlusconi and Orbán are both

13 As often cited, Berlusconi said at a press conference that 'Life in Italy is the life of a wealthy country: consumption hasn't diminished, it's hard to find seats on planes, our restaurants are full of people.' (Libero Quotidiano 2011) 
innovative politicians who have effected massive changes in the dimension of politics: they have applied new tactics in the relationship with their followers and have profoundly transformed the party system and the political spectrum. Otherwise, Berlusconi has been less effective in the fulfilment of his policy goals (see Pasquino 2012: 140), and, with the exception of electoral reform, has failed to carry out major institutional (constitutional) reform. In contrast, Orbán has been more effective at transforming policy means and priorities, and has been more successful at achieving wider political goals such as redefining the boundaries between state and society, constitution-making, and transforming the electoral system and other elements of the institutional political system. The results of the comparison are presented in Table 1.

Table 1 The effect of Berlusconi and Orbán on the three political dimensions

\begin{tabular}{cccc}
\hline & Political dimensions & Berlusconi & Orbán \\
\hline Politics & (1) Party system and political spectrum* & + & + \\
& (2) Political means & + & + \\
Polity & (3) Political institution system & - & + \\
Policy & (4) Policy and wider political goals & - & + \\
\hline
\end{tabular}

*Electoral reforms are included in this category.

Populism. Common to Berlusconi and Orbán is the populist nature of their politics and leadership. We found that both pursued populist strategies in the ideological sense and in the sense of populism as process and linkage, but they did not integrate elements of direct democracy into the respective constitutional systems. In this respect, their activity has been different from some previous examples of populism (e.g. in the United States in the late nineteenth and early twentieth century, or the Fifth Republic of de Gaulle). They have often justified their policies by referring to the will of the people vis-à-vis elite politics, but their populism is an instrument of a top-down political leadership rather than a concrete institutionalization of decision-making by the people.

Direction of change. Reviewing their political activities (Table 2) we can state that without Berlusconi and Orbán, Italian and Hungarian politics would have been decidedly different. As we can see, both Berlusconi and Orbán played a prominent role in speeding up the tendency to personalize the elections. To sum up, they have contributed to a large extent to the presidentialization process (Poguntke and Webb, 2005). Although presidentialization has proved to be a general phenomenon in European politics, Berlusconi and Orbán have played 
an outstanding role in this field. What makes their performance exceptional is especially the extent of the personalization of Berlusconi's party and electoral campaign, and the extent of the presidentialization of the executive by Orbán (Calise 2005; Fabbrini 2012; Körösényi 2001). Orbán's second and third terms might be labelled 'elected dictatorship', since his control of the party, the executive and the legislature has reached an extraordinarily high level, and his power and influence now extend over the sphere of finance and the economy.

Table 2 Overview of the politics of Berlusconi and Orbán

\begin{tabular}{|c|c|c|}
\hline & Berlusconi & Orbán \\
\hline \multirow{4}{*}{ Similarities } & Weakening of the rule of law & Weakening of the rule of law \\
\hline & Populist & Populist \\
\hline & Personalization and presidentialization & Personalization and presidentialization \\
\hline & New era (dimension of politics) & New era (dimension of politics) \\
\hline \multirow{5}{*}{ Differences } & Market-liberal and capitalist & Etatist and anti-capitalist \\
\hline & Rather liberal (values, attitudes) & $\begin{array}{c}\text { Strong anti-liberal elements (values, } \\
\text { attitudes) }\end{array}$ \\
\hline & Normal politics & Extraordinary politics \\
\hline & Transactive leader & Transformational leader \\
\hline & $\begin{array}{l}\text { Regime maintainer (dimension of } \\
\text { polity) }\end{array}$ & Regime founder (dimension of polity) \\
\hline
\end{tabular}

The substantive emptiness of their populist ideology ('thin ideology') is confirmed by our findings in the sense that while we found identical features in the political methods and means of Berlusconi and Orbán, we also identified significant differences in the content of their ideologies and political programs. Their attitude to liberalism is completely different. 'Berlusconism', as Orsina says, is an 'emulsion of liberalism and populism' (Orsina 2013: 129). Berlusconi used the legislature to gain personal advantages, but his worldview is rather liberal; this is captured in individualist values, in his firm faith in civil society, and in economic preferences for markets and liberal capitalism. He weakened the rule of law by ad personam legislation, but did not use similar means to transform the political regime. Orbán, by contrast, weakened constitutional limitations on his power in a systematic manner. ${ }^{14}$ Since Orbán entered into office in 2010, the liberal-constitutionalist elements of the Hungarian constitution have been markedly weakened. The economic policy

14 For the illiberal elements of the Fundamental Law introduced by the Orbán cabinet from 2012, see Bánkuti et. al 2012; Jenne and Mudde 2012. 
followed by Orbán has strong etatist, anti-capitalist and anti-market elements, so it has proved to be in many aspects anti-liberal. His political discourse and rhetoric may also be characterized by his anti-liberalism.

The strong similarities in the personalization of politics and their populism conceal crucial differences in personal political aims and ambitions, leadership types, public policy attitudes, relations to the status quo and institutional and policy reforms. The differences may be traced back to the divergence in their career paths. Unlike Orbán, who became a professional politician during the years of democratization of Hungary, Berlusconi broke into politics as an outsider, well-known for his professionalism and business expertise, and with a considerable amount of economic capital. While the fame he gained as a businessman has been a fundamental resource for his political success, his personal wealth and his media empire were also of major importance. The showman, however, is veiling a socially conservative, status-quo-oriented attitude. His political career path and personal aims (to defend personal business interests and overcome the legal procedures against him) also explain his more right-leaning political attitude (i.e. his determination to block the communist party and the left). The scope and extent of political changes in institutions, state, and society proved to be rather limited in Berlusconi's case. Changes include the electoral arena, the electoral law and the party system, but only minor changes have been made to government institutions. His most ambitious constitutional reform plan failed in 2006. All in all, the policy and legislative measures of Berlusconi cabinets remained within the frameworks of 'normal politics', and also within the borders of conventional bürgerliche politics. The policy and politics of Orbán from 2010 onwards, in contrast, have transcended both of these borders, and his political methods recall times of 'extraordinary politics' (Agamben 2005; Boin et al. 2012; Kalyvas 2008).

The Berlusconi era brought revolutionary changes in terms of electoral campaigns, reform of the style and language of politics, the party system and links to the people, and in some respects was a model which inspired the politics of Orbán. But the changes carried out to the Italian system did not include changes to the machinery of the state and redistribution of income and wealth, and modification of the relation between state and society. In contrast, Orbán's ambitions transcend the party system and have included changes to the whole political system, such as reforms of the state and changes to the relation between state and society. Changes since 2010 have included modifications to the whole system of government, public administration, the constitution, relations between state and economy, and the redistribution of income and wealth. Orbán has gone much further in changing the political system and in institutionalizing his power, and the robustness of these changes is far beyond that of Berlusconi's. 
He has not merely launched a new era in Hungarian politics, like Berlusconi in Italy, but since 2010 has become the founder of a new political regime; a democracy with strong authoritarian element.

\section{REFERENCES}

Agamben, Giorgio (2005), State of Exception, Chicago, University of Chicago Press

Bánkuti, Miklós, Halmai, Gábor and Scheppele, Kim Lane (2012), Disabling the Constitution, Journal of Democracy, Vol. 23 No. 3, pp. 138-146. doi:10.1353/ jod.2012.0054

Bellamy, Richard (2007), Political Constitutionalism: A Republican Defense of the Constitutionality of Democracy. Cambridge, Cambridge University Press

Boin, Arjen, 't Hart, Paul and van Esch, Femke (2012), 'Political Leadership in Times of Crisis: Comparing Leader Responses to Financial Turbulence', in: Helms, L. ed. Comparative Poilitical Leadership, Basingstoke, Palgrave MacMillan, pp. 119-141.

Bozóki András (2008), Consolidation or Second Revolution? The Emergence of the New Right in Hungary. Journal of Communist Studies and Transition Politics. Vol. 24 No. 2. pp. 191-231. doi:10.1080/13523270802003046

Blondel, Jean and Thiebault, Jean-Louis (eds.) (2010), Political Leadership, Parties and Citizens: The personalisation of leadership, London and New York, Routledge

Bull, Martin J. \& Newell, James L. (2009), Still the Anomalous Democracy? Politics and Institutions in Italy. Government and Opposition, Vol. 44, No. 1, pp. 42-67. doi: 10.1111/j.1477-7053.2008.01275.x

Burns, James MacGregor (1978), Leadership, New York, Harper and Row

Calise, Mauro (2005), Presidentialization, Italian Style, in: Poguntke, T. and Webb, P. eds. The Presidentialization of Politics: A Comparative Study of Modern Democracies, Oxford, Oxford University Press

Campus, Donatella (2006), L'antipolitica al governo: De Gaulle, Reagan, Berlusconi, Bologna, Il Mulino

Canovan, Margaret (1999), Trust the People! Populism and the Two Faces of Democracy, Political Studies, Vol. 47, No. 1, pp. 1-16. doi:10.1111/14679248.00184

Carstensen, Martin B. (2011), Paradigm man vs. the bricoleur: bricolage as an alternative vision of agency in ideational change, European Political Science Review, Vol. 3, No.1, pp. 147 - 167. doi.org/10.1017/S1755773910000342 
Conversi, Daniele (2013), Lessons from the past? Europe's grand shift from cultural homogenization to multiculturalism, in: McMahon, R. (Ed.), PostIdentity?: Culture and European Integration, Routledge

Enyedi Zsolt (2005), The Role of Agency in Cleavage Formation. European Journal of Political Research, Vol. 44, No. 5, pp. 697-720. doi: 10.1111/j.14756765.2005.00244.x

- and Casal Bertoa, Fernando. (2011), Patterns of party competition (19902009). in: Lewis, Paul and Markowski, Radoslaw (eds.), Europeanizing party politics? Comparative perspectives on Central and Eastern Europe after Enlargement, Manchester, Manchester University Press

Fabbrini, Sergio (2013), The rise and fall of Silvio Berlusconi: Personalization of politics and its limits. Comparative European Politics, Vol. 11, No. 2, pp. 153-171. Forza Italia (2013a), 'Berlusconi: in campo con Forza Italia', 18 September, www.forzaitalia.it/notizie/10013/il-messaggio-del-presidente

(2013b), 'I primi vent'anni con Silvio', 10 December, www.forzaitalia.it/ libri/i-primi-ventanni-con-silvio/

Jenne, Erin. K. and Mudde, Cas (2012), Can Outsiders Help? Journal of Democracy, Vol. 23, No. 3, pp. 147-155. doi: 10.1353/jod.2012.0057

Kalyvas, Andreas (2008), Democracy and the Politics of the Extraordinary: Max Weber, Carl Schmitt, and Hannah Arendt, Cambridge and New York, Cambridge University Press

Karvonen, Lauri (2010), The Personalisation of Politics, Colchester, ECPR Press

Körösényi, András (2001), Parlamentáris vagy 'elnöki’ kormányzás? Az Orbánkormány összehasonlító perspektívából. Századvég, Új folyam, No. 20, pp. $3-38$.

- (2013), Political Polarization and its Consequences on Democratic Accountability. Corvinus Journal of Sociology and Social Policy, Vol. 4, No. 2, pp. 111-138. doi:10.14267/cjssp.v4i2.84

Körösényi, András and Patkós, Veronika (2017), Variations for Inspirational Leadership: The Incumbency of Berlusconi and Orbán. Parliamentary Affairs, Vol. 70, No. 3, pp. 611-632. doi:10.1093/pa/gsx004

Libero Quotidiano (2011), 'Crisi in Italia? Ma se I ristoranti sono pieni', Libero Quotidiano, 4 November, http://tv.liberoquotidiano.it/video/1548304/-Crisiin-Italia--ma.html

Magyar Narancs (2003), Polgári körök váraljai országos találkozója: Következmények nélkül. Magyar Narancs, 3 September.

Mair, Peter (2002), Populist Democracy vs. Party Democracy, in: Democracies and the Populist Challange, edited by Mény, Y. and Surel, Y. Basingstoke, Palgrave, pp. 81-97. 
Mény, Yves and Surel, Yves (eds.) (2002), Democracies and the Populist Challenge, Basingstoke, Palgrave

Moroni, Chiara (2008), Da Forza Italia al Popolo della Libertà, Roma, Carocci Mudde, Cas (2004), 'The Populist Zeitgeist,' Government and Opposition Vol. 39, No. 4, pp. 541-563.

Mudde, Cas (2015). Populism in Europe: a primer. OpenDemocracy. URL https://www.opendemocracy.net/can-europe-make-it/cas-mudde/populismin-europe-primer (accessed 1.19.16).

Mudde, Cas and Kaltwasser, Cristobal Rovira (2014), 'Populism and political leadership', in: Rhodes, Rod A. W. and 't Hart, Paul (eds.) The Oxford Handbook of Political Leadership, Oxford, Oxford University Press, pp. $376-388$.

Orsina, Giovanni (2013), Il berlusconismo nella storia d'Italia, Venezia, Marsilio Editori

Palonen, Emilia (2009), Political polarisation and populism in contemporary Hungary. Parliamentary Affairs. 62, 318-334. doi:10.1093/pa/gsn048

Pappas, Takis. (2014), Populist democracies: Post-authoritarian Greece and Post-communist Hungary, Government and Opposition, Vol. 49, No. 1, pp. 1-23. doi:10.1017/gov.2013.21

Pasquino, Gianfranco (2005), Populism and Democracy. The John Hopkins University: The Bologna Center: Seminar Series Occasional Papers (3):737.

(2007a), The five faces of Silvio Berlusconi: The knight of anti-politics. Modern Italy, Vol. 12, No. 1, pp. 39-54. doi:10.1080/13532940601134817

—_ (2007b), Tricks and treats: the 2005 Italian electoral law and its consequences. South European Society \& Politics, Vol. 12, No. 1, pp. 79-93. doi: 10.1080/13608740601155500

(2012), 'Italy: goodness, badness, and the trajectory of mediocrity', in L. Helms (ed.), Poor Leadership and Bad Governance, Edward Elgar, Cheltenham-Northampton, pp. 130-148.

Pelinka, Anton. (1995), Leadership, Democratic Theory, and the 'Lesser Evil'. Discussion paper No. 12, December 1995, Collegium Budapest, Institute for Advanced Study.

Poguntke, Thomas and Webb, Paul eds., (2005), The Presidentialization of Politics: A Comparative Study of Modern Democracies. Oxford, Oxford University Press

Poli, Emanuela (2001), Forza Italia. Strutture, leadership e radicamento territoriale. Bologna, Il Mulino

Di Quirico, Roberto (2010), Italy and the global economic crisis. Bulletin of Italian Politics, Vol. 2, No. 2, pp. 3-19. 
Raniolo, Francesco (2006), Forza Italia: a leader with a party. South European Society \& Politics, Vol. 11, No. 3-4, pp. 439-455. doi:10.1080/13608740600856470

Renwick, Alan, Hanretty, Chris and Hine, David (2009), Partisan self-interest and electoral reform: The new Italian electoral law of 2005. Electoral Studies, Vol. 28, No. 3, pp. 437-447. doi:10.1016/j.electstud.2009.04.003

Reuters, (2014), Merkel says EU must create jobs to counter populist wave.

Socialists \& Democrats, (2015), 'Orbán is reminiscent of Berlusconi and an embarrassment for Hungary' says Pittella. http://www.socialistsanddemocrats. eu. URL http://www.socialistsanddemocrats.eu/newsroom/orb\%C3\%A1nreminiscent-berlusconi-and-embarrassment-hungary-says-pittella (accessed 1.19.16).

Spiegel Online, (2010), Media Law Outrage: Hungary's 'Orbanization' Is Worrying Europe. Spiegel ONLINE. URL http://www.spiegel.de/ international/europe/media-law-outrage-hungary-s-orbanization-isworrying-europe-a-736706.html (accessed 1.19.16).

Sartori, Giovanni (1976), Parties and Party Systems, Cambridge, New York and Melbourne, Cambridge University Press

Schmidt, A. Vivien (2014), Speaking to the Markets or to the People? A Discursive Analysis of the EU's Sovereign Debt Crisis. The British Journal of Politics and International Relations, Vol. 16, No. 1, pp. 188-209. doi:10.1111/1467856X.12023

The Economist, (2012), To Viktor too many spoils. http://www.economist.com/ node/21542414 (accessed 1.19.16).

Stille, Alexander (2012), Citizen Berlusconi, il Cavalier miracolo: la vita, le imprese, la politica. Garzanti, Milano.

Szűcs, Zoltán Gábor (2012), A magyar politikai diskurzus változásai 2000 óta. in: Boda Zsolt - Körösényi András (eds.): Van irány? Trendek a magyar politikában. Budapest, MTA TK PTI - ÚMK, pp. 128-151.

Zakaria, Fareed (1997), The Rise of Illiberal Democracy. Foreign Affairs, Vol. 76, No. 6, pp. $22-43$. 
